
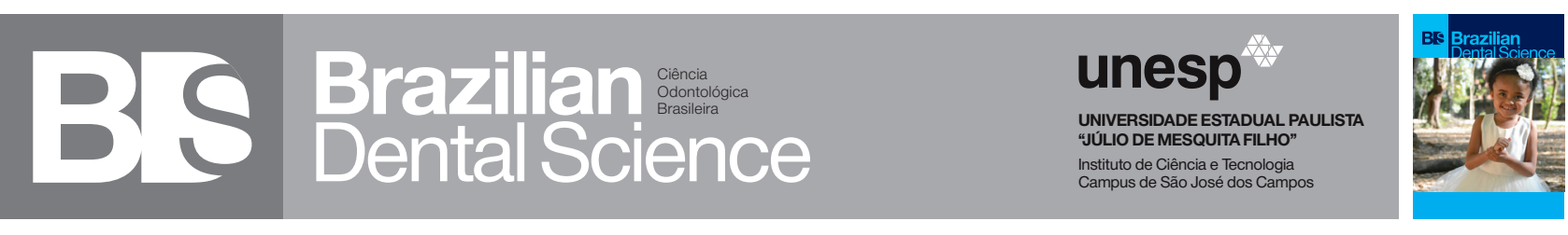

\title{
Effects of ovariectomy, estrogen and soy isoflavones in rats submandibular glands
}

Efeitos da ovariectomia, estrógeno e isoflavonas da soja em glândulas sumandibulares de ratos

Luana Marotta Reis VASCONCELLOS ${ }^{1}$, Vanessa Avila Sarmento SILVEIRA ${ }^{1}$, Raphaella Silveira MEDEIROS ${ }^{1}$, Márian Yaktin AMORIM ${ }^{1}$, Yasmin Rodarte CARVALHO ${ }^{1}$, Renata Falchete PRADO ${ }^{1}$

1 - São Paulo State University (Unesp) - Institute of Science and Technology - São José dos Campos - Department of Biosciences and Oral Diagnosis - SP - Brazil.

\begin{abstract}
Objective: A decrease in granular convoluted tubule (GCT) cells and acini occurs in the submandibular glands of castrated female rats, while in rats submitted to hormone replacement and phytotherapy with soy isoflavones, this effect is reversed. This study aimed to elucidate the mechanisms through which these changes occur. Material and Methods: Rats $(n=84)$ were ovariectomized and 21 were sham-operated. Ovariectomized rats were randomly subdivided and orally administered the following: $17 \quad \beta$-estradiol (OVX-E; $\mathrm{n}=21$ ), $15 \mathrm{mg} / \mathrm{kg} /$ day of soy isoflavone extract (OVX-I; $\mathrm{n}=21$ ), $17 \beta$-estradiol + soy isoflavone extract (OVX-A; $\mathrm{n}=21)$; and water as placebo (OVX; $\mathrm{n}=21$ ). The rats were euthanized three, five and eight weeks after ovariectomy. The submandibular salivary glands were submitted to histological processing with HE stain and immunohistochemistry was performed using the streptavidin-biotinperoxidase complex. The cell area and the expression of proliferating cell nuclear antigen and estrogen receptor $\beta$ were evaluated. Results: The results were statistically analyzed by ANOVA and Tukey test. A decrease in the area of GCT cells in the OVX, was observed, in contrast with an increase in the OVX-E. PCNA in the acinar cells and estrogen receptors were elevated in the OVX-I group. Conclusion: Castration exerts an immediate reductive effect on the volume of GCT cells. Estrogens, soy isoflavones and their combination have different mechanisms of action on the homeostasis of the gland. Estrogens cause an increase in GCT cells area, while isoflavones enhance cell proliferation and the expression of estrogen receptor- $\beta$. Their association showed no additional increase in the effect studied.
\end{abstract}

\section{KEYWORDS}

Estrogen; Morphometry; Salivary glands; Soy isoflavones.

\section{RESUMO}

Objetivo: Diminuição das células granulares do túbulo contorcido granular e dos ácinos ocorre nas glândulas submandibulares de ratas fêmeas ovariectomizadas, enquanto que nas ratas submetidas a reposição hormonal e fitoterapia com isoflavona da soja, este efeito é revertido. Este estudo tem como objetivo elucidar os mecanismos pelo qual estas alterações ocorrem. Material e Métodos: 84 ratas foram ovariectomizadas e 21 foram sham-operatadas. As ratas ovariectomizadas foram aleatoriamente subdivididas e receberam administração oral dos seguintes medicamentos: $17 \beta$-estradiol (OVX-E; $\mathrm{n}=21$ ), $15 \mathrm{mg}$ / $\mathrm{kg}$ /day do extrato de isoflavona da soja (OVX-I; $n=21$ ), $17 \beta$-estradiol + extrato de isoflavona da soja (OVX-A; $\mathrm{n}=21$ ); e água como placebo (OVX; $\mathrm{n}=21$ ). As ratas foram eutanasiadas 3,5 e 8 semanas após a ovariectomia. As glândulas submandibulares foram submetidas a análise histológica por meio do processamento histológico de coloração com $\mathrm{HE}$ e imunohistoquímica utilizando o complexo peroxidase-biotina-streptavidina. A área celular e a expressão do antígeno de proliferação celular nuclear e receptor $\beta$ estrogênico foram avaliados. Resultados: Os resultados foram estatisticamente analisados por meio do teste ANOVA e Tukey. Foi observada diminuição na área de células GCT cells no grupo OVX, em contraste com o aumento no grupoe OVX-E. PCNA nas células acinares e receptores de estrógeno estavam aumentados no grupo OVX-I. Conclusão: A castração exerce um efeito indutivo imediato no volume das células GCT. Estrógeno, isoflavona da soja e sua combinação têm diferentes mecanismos de ação sobre a homeostase da glândula. Estrógeno causa um aumento da área de células GCT, enquanto a isoflavona aumenta a proliferação celular e a expressão do receptor- $\beta$ de estrógeno. A associação destes não mostrou aumento adicional nos efeitos estudados.

\section{PALAVRAS-CHAVE}

Estrógeno; Morfometria; Glândula salivar; Isoflavona da soja. 


\section{INTRODUCTION}

The perimenopause or menopause the ovaries cease their function, usually a slow and gradual process, and is responsible for a series of changes in the female organism [1]. Due to estrogen deficiency, the systemic aspects of menopause manifest at this stage. The main issues are hot flashes, excessive sweating and vaginal atrophy [2]. Oral manifestations have been reported, including changes in salivation and taste, gingivitis and recurrent bleeding [3].

Salivary glands are not classic target organs of female sex hormones, but the influence of these hormones on these glands has been studied [4-7]; however, knowledge concerning this interaction remains scarce.

Estrogen receptors (ER) have been identified in human submandibular salivary glands of specimens evaluated by RT-PCR by Leimola-Virtanen et al. [8]. The oral mucosa displays specific receptors that recognize these ovarian hormones connecting them to the cytoplasm or nucleus. A deficiency of sex hormones, particularly estrogen, results in changes in the oral mucosa at the tissue level, since these hormones seem to control the proliferation, differentiation and keratinization of the gingival epithelium and stimulate the proliferation of fibroblasts [9].

Sex hormones seem to regulate salivary gland function. Streckfus et al. [10] analyzed and compared the rates of salivary flow in stimulated and non-stimulated glands, showing a relationship between flow decrease in advancing age and decreasing levels of estrogen production.

The harmful effects of the use of estrogen hormone replacement therapy, such as the increased risk of developing adenocarcinoma, is encouraging researchers to find new treatments for the effects of menopause [11]. Giuca et al. [3] evaluated the efficacy of hormone replacement therapy (HRT) and herbal therapy in postmenopausal women with oral discomfort. According to the authors, oral symptoms abated or decreased in women with both therapies. Both estrogens and phytoestrogens are promising, including the reduction of tooth loss during menopause due to osteopenia and osteoporosis.

In salivary glands, Katz et al. [12] demonstrated that isoflavones (genistein and soy phytochemical concentrate) cause the inhibition of cell proliferation in glandular lineage cultures, derived from a patient submitted to anticancer radiation therapy. Soy isoflavone was extracted by using ethanol as a solvent, with a resulting $49 \%$ weight concentration obtained. In a soy isoflavone concentration of $75 \mu \mathrm{g} / \mathrm{ml}$, which inhibits DNA synthesis by 50\%, $6.0 \mu \mathrm{g} / \mathrm{ml}(22$ $\mu \mathrm{M})$ of genistein and $4.3 \mu \mathrm{g} / \mathrm{ml}(17 \mu \mathrm{M})$ of daidzein were found.

In castrated rats, Chaves Carvalho et al. reported a decrease in the volume density of granular convoluted tubule cells and acini in the submandibular glands. They also reported that in rats administered hormone replacement, herbal medicines, or a combination of both, the effect of ovariectomy did not affect the morphometric values of these structures in the glands. The decrease in the ovariectomized group may occur due to a reduction in the volume of the cells or due to a decrease in the total number of cells by apoptosis, for example. Therapies appear to be effective in returning normal cell volume and inducing cell proliferation when administered to rats [4].

To explain the mechanisms by which these phenomena occur, we evaluated the cellular area using histomorphometry and the immunohistochemical expression of proliferating cell nuclear antigen (PCNA). Since the estrogen receptor- $\beta$ is the predominant estrogen receptor subtype in the human oral epithelium and salivary glands [28], the receptor- $\beta$ was accessed using immunohistochemistry. 


\section{MATERIAL AND METHODS}

\section{Animals}

One hundred and five 90 days old female adult rats (Rattus norvegicus, Albinus variation, Wistar) weighing approximately $300 \mathrm{~g}$ were selected. They were maintained in cages at room temperature provided by the vivarium of the Institute of Science and Technology, São José dos Campos Dental School of São Paulo State University (ICT-UNESP) and fed with commercial diets and water ad libitum. The amount of feed ingested per day was predetermined to avoid uncontrolled increase in the weight of the rats. This study was conducted according to the Ethical Principles in Animal Experimentation (COBEA) and was approved by the Research Ethics Committee of the ICTUNESP, under protocol no. 029/2004/PA-CEP.

The rats were randomly divided into two groups: Ovariectomized (OVX) and SHAM. The OVX animals, consisting of 84 rats were submitted to ovariectomy, and subsequently randomly subdivided into four groups, each of 21 females, according to the treatment administered:

a) The estrogen group (OVX-E), administered $1 \mathrm{mg} / \mathrm{kg} /$ day valerate 17 $\beta$-estradiol orally;

b) The isoflavone group (OVX-I), administered $15 \mathrm{mg} / \mathrm{kg} /$ day of soy isoflavones $40 \%$ orally;

c) The associated group (OVX-A), administered $1 \mathrm{mg} / \mathrm{kg} /$ day valerate 17 $\beta$-estradiol associated with $15 \mathrm{mg} / \mathrm{kg} /$ day of soy isoflavones $40 \%$ orally;

d) The placebo ovariectomized group (OVX), administered placebo (water) orally.

The rats of the SHAM group consisted of 21 rats that underwent a faked surgical intervention. They were also administered placebo (water) orally each day. Rats were dosed, by gavage, 7 days per week for 3, 5 and 8 consecutive weeks, starting from the day after ovariectomy.
All rats were weighed at the onset of the experiment and were reweighed on the day of euthanasia, but they were detailed elsewhere [11]

General anesthesia was administered intramuscularly using a solution of $13 \mathrm{mg} / \mathrm{kg}$ of methyl 2-(2,6-xylidine)-5,6-dihydro-4H-1,3thiazine (Rompun-Bayer Brazil, São Paulo-SP), sedative, analgesic and muscle relaxant and $33 \mathrm{mg} / \mathrm{kg}$ ketamine base (Dopalen - Agribands of Brazil Ltda, Paulínia-SP).

Following anesthesia, the rats in ovariectomized group were shaved in the lateral region of the body at the level of the kidneys and below the lowest rib and antisepsis was performed with iodine alcohol. A longitudinal incision was performed measuring $1 \mathrm{~cm}$ on average. Following the muscle incision, a dressing was made to contain the bleeding and the ovaries were exposed and removed bilaterally.

False ovariectomy or sham surgery was performed on the rats from the Sham group, in which the same procedures were followed, including exposure of the ovaries, without the ligature and excision of the organ.

At the end of the procedure, the muscle layer was sutured with resorbable catgut thread no.4 (Cirumédica, Belo Horizonte, Minas Gerais, Brazil), followed by skin suture with 4.0 silk thread (Ethicon, Johnson \& Johnson São José dos Campos, SP, Brasil), and repetition of antisepsis with iodine alcohol in the operated region.

Five rats from each group/subgroup of 15 were euthanized at three different time points: three, five and eight weeks post-ovariectomy, using a lethal injection of anesthetic. Their submandibular and sublingual glands were dissected and fixed in 10\% formalin for approximately $48 \mathrm{~h}$.

\section{Treatments administered}

Pills of valerate17 $\beta$-estradiol, $1 \mathrm{mg}$ (Primogyna - Shering SA São Paulo, Brasil), were used to administer the dose of $1 \mathrm{mg} / \mathrm{kg} /$ day to rats, dose previously used by Mvondo et al. 
[13]. The drug was macerated, suspended in distilled water and administered to each rat.

The herbal medicine used was a $40 \%$ soy isoflavones extract from the Glycine max grain (L.) Merril, Leguminosae, provided by the Botanical Herbarium Laboratory. The isoflavone extract is commercially available as Isoflavine ${ }^{\circledR}$, and uses soybean oil as an excipient (Herbarium Botanical Laboratory Ltda, Colombo, Paraná, Brazil).

Table 1 - Quantification of the isoflavones according to Herbarium Botanical Laboratory Ltda.

\begin{tabular}{|lc|}
\hline Type of isoflavones of the extract $40 \%$ & Molecular mass \\
\hline Glycitin & $446.41 \mathrm{~g} / \mathrm{mol}$ \\
\hline Glycitein & $284.30 \mathrm{~g} / \mathrm{mol}$ \\
\hline Genistin & $432.38 \mathrm{~g} / \mathrm{mol}$ \\
\hline Genistein & $270.23 \mathrm{~g} / \mathrm{mol}$ \\
\hline Daidzin & $416.38 \mathrm{~g} / \mathrm{mol}$ \\
\hline Daidzein & $254.24 \mathrm{~g} / \mathrm{mol}$ \\
\hline
\end{tabular}

In 2003, Genovese et al. [14] determined that Isoflavine ${ }^{\circledR}$ contained 1,5\% a-glycoside, 53\% aglycones and 45\% $\beta$-glycoside. Between isoflavones, $29.7 \pm$ $0.5 \%$ was total daidzein, $64.6 \pm 0.4 \%$ was total genistein and $5.7 \pm 0.1 \%$ was total glycitein.

The extract was suspended in distilled water. The laboratory quantified the principal following types of isoflavones (Table 1). Each rat received $15 \mathrm{mg} / \mathrm{kg} /$ day of soy isoflavones orally. The $15 \mathrm{mg} / \mathrm{kg} / \mathrm{d}$ dose of soy isoflavone $40 \%$ extract was selected because similar doses are believed to be effective in preventing experimental osteoporosis without causing stimulation in the uterus $[15,16]$.

\section{Tissue processing and immunohistochemistry}

Following fixation, the left submandibular glands of each group were dissected, washed, dehydrated, cleared in xylene and embedded in paraffin blocks. Five semi-serial sections were obtained from each rat, with $100 \mathrm{~mm}$ intervals. These were stained by conventional hematoxylin and eosin (HE), and subsequently photographed for the histomorphometric analysis.

For immunohistochemical analysis, $3 \mu \mathrm{m}$ sections were stretched on silanized slides treated with 3-aminopropyl-triethoxysilane (Sigma Chemical Company, Saint Louis USA) for staining to detect estrogen receptor- $\beta$ and PCNA.

One section of each rat $(n=5$, antigen retrieval resulted in areduced number of immunohistochemical stained slides), totalizing 75 slices for each antibody were deparaffinized in xylene, rehydrated in solutions with decreasing concentrations of ethanol and washed in running water. Antigen retrieval was performed in citrate buffer ( $\mathrm{pH}$ 6.0) in a microwave. The endogenous peroxidase activity was blocked with 6\% $\mathrm{H} 2 \mathrm{O} 2$ and methanol.

The primary antibodies were: polyclonal anti-estrogen receptor beta antibody (Abcam ab3576 Cambridge, MA, USA) and monoclonal anti-nuclear antigen of cellular proliferation (PC10, DAKO, Carpinteria, USA) incubated 1:100, and 1:75 respectively, overnight at 4oC. A labeled streptavidin-biotin-peroxidase (LSAB) kit (Dako, Carpinteria, USA) was used. The chromogenic substrate used was diaminobenzidine (DAB, Sigma, Saint Louis USA). The sections were counter-stained with Mayer's hematoxylin (Dako, Carpinteria, USA) and mounted with Permount.

\section{Analysis of the results}

Histomorphometric and immunohistochemical analysis were performed as blinded randomized controlled trials. In each group of 7 rats, a total of 35 slides were obtained, with a total of 10 granular convoluted tubule (GCT) cells ( 2 cells per field, one field per semi-serial slice). A total of 10 acini cells were randomly identified in the same fields used to count the GCT cells.

Analysis of the cell area was performed on 5 random microscopic serial fields (HEstained) 
obtained using Zeiss Axiophot 2 microscope (Carl Zeiss, Oberkochen, Germany) with a 10X ocular and 40X objective, coupled to an Axiocam MRC5 digital camera (Carl Zeiss, Oberkochen, Germany).

The AxioVisionRel 4.7 (Carl Zeiss, Oberkochen, Germany) software was used tooutline randomly selected cell membrane of cells of acini and ducts, and calculate the resulting area $(\mu \mathrm{m} 2)$. Ten cells of the granular ducts and other 10 cells of acini were outlined and the mean area obtained.

The results of the immunohistochemical reactions were examined under an optical microscope. Five fields per slide were photographed using the same equipment mentioned above. For estrogen receptor- $\beta$, analysis of the percentage of glandular cells was performed, attributing the following scores: $0=$ no positive glandular cells; $1=$ less than $25 \%$ positive glandular cells; $2=26$ to $50 \%$ positive glandular cells; $3=51$ to $75 \%$ positive glandular cells; and $4=$ more than $75 \%$ positive glandular cells. The scoring processes described above resulted in one value per field and a mean value of ER- $\beta$ expression per rat.

For the analysis of PCNA, microscopic fields with the highest density [hot-spots] were identified using 100x magnification. These were subsequently photographed at $400 \mathrm{x}$ magnification. Three hundred acinar and GCT cells were analyzed with positive brown cells counted and expressed in absolute numbers. The values of all 15 groups were used in the statistical approach (5 values per group).

\section{Statistical analysis}

Statistical analysis was performed on the average values per rat. Data was analyzed descriptively and inferentially using two-way ANOVA. The variables were euthanasia time (3, 5 and 8 weeks) and treatment used (SHAM, OVX, OVX-E. OVX-I, OVX-A). The Tukey test was used for multiple comparisons. A value of $5 \%$ was used as the significance criterion.

Five statistical approaches were performed: ANOVA and Tukey test for acinar cells area data, ANOVA and Tukey test for GCT cell area data, ANOVA and Tukey test for PCNA positive acinar cells data, and ANOVA and Tukey test for PCNA positive GCT cells. The latter compared the mean values of scores obtained from each ER[ immunostained slide, according to rat treatment and euthanasia time.

\section{RESULTS}

The Kappa test was used in the analyses to determine the calibration of the examiner and substantial agreement (0.70) was observed.

\section{Size of acinar cells}

ANOVA showed that the time of euthanasia, the experimental group and the interaction between them had significant effects ( $p \leq 0.05$ ). At the earliest time point, the SHAM group (Figure 1a and Figure 2) presented the largest mean cell area, but this was not significantly different from the OVX (Figure $1 \mathrm{~b}$ and Figure 2) and OVX-A (figure 1e and figure 2) groups for the same period. At 8 weeks, the OVX-A and OVX-E (Figure 1c and Figure 2) groups presented small averages of acinar cell area. At 8 weeks, both SHAM and OVX-I (Figure 1d and Figure 2) groups presented the highest average acinar cell area. 


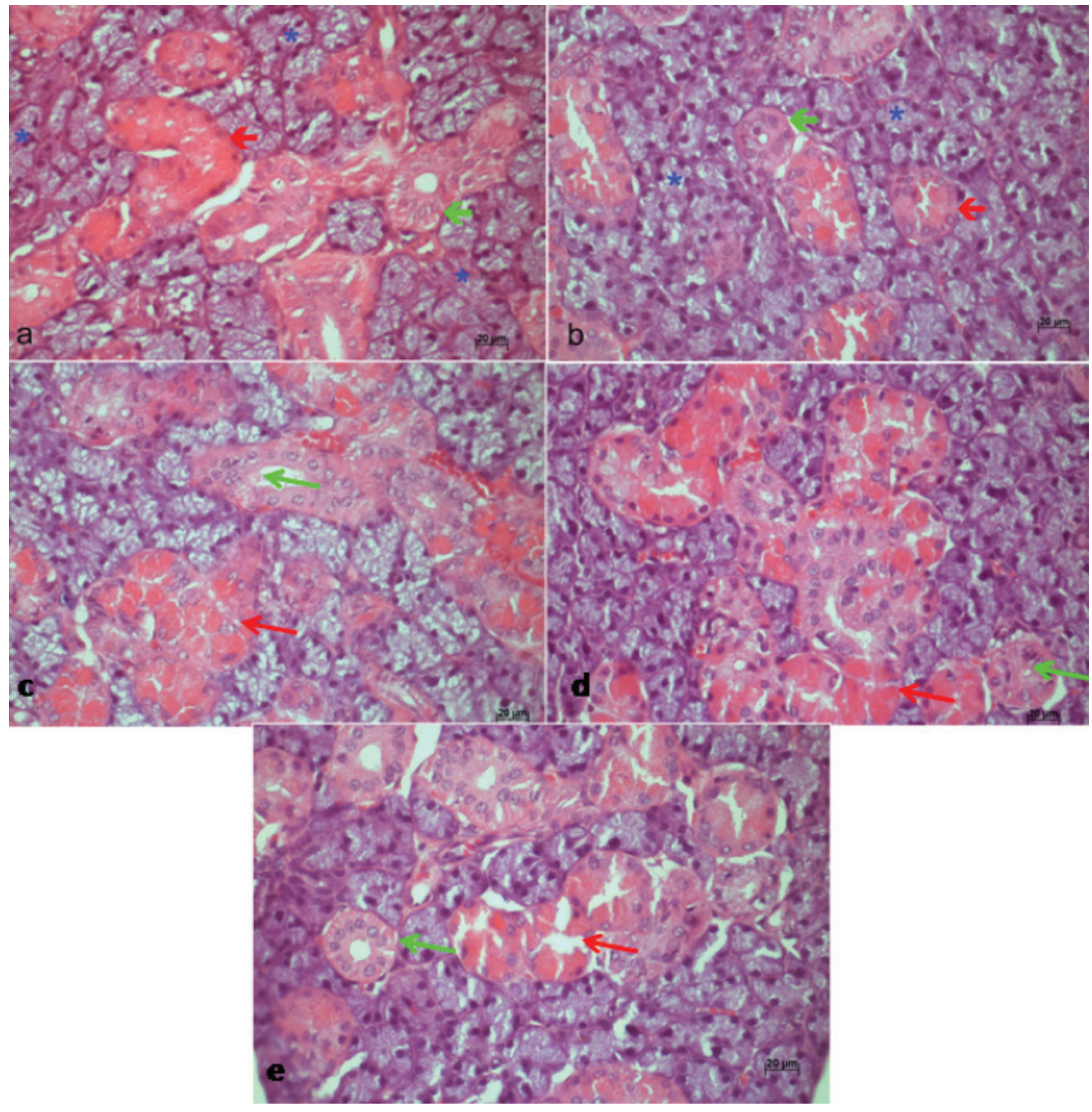

Figure 1 - Submandibular gland presenting predominantly serous acini. Acinar cells in rat submandibular glands are polarized cells, described as pyramidal, with a wide base facing the basal lamina. HE cuts show oval cells with eccentric nucleus and large basophilic cytoplasm, rich in secretory vacuoles (blue mark). Granular convoluted tubule (GCT) cells containing secretory granules are shown strongly stained by eosin, acquiring an almost red shade. Their lumens frequently display secretory granules (red arrow). Striated duct cells are columnar and contain longitudinal striation. Their lumens are usually well round and demarcated (green arrow). A) SHAM group at 3 weeks. GCT cells are big and completely filled by red granules B) OVX group at 3 weeks. GCT cells present a smaller area and less granules compared to SHAM. 


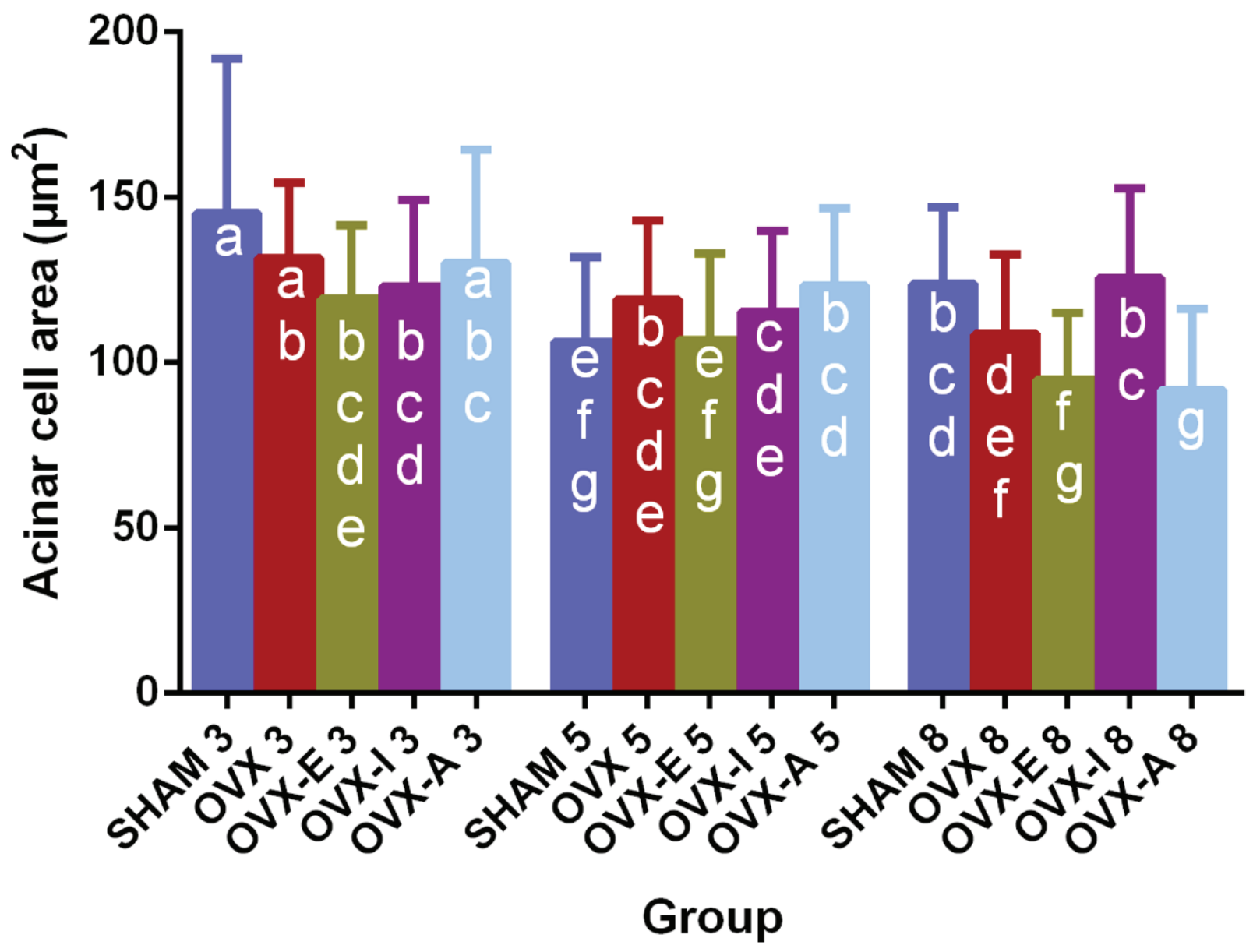

Figure 2 - Effects of ovariectomy and different treatments on acinar cells area. Bar charts indicate the average and standard deviation for each group. The number of animals evaluated for each cohort was $n=15$ (Sham 3, 5 and 8 weeks, $n=5)$, $n=15$ (OVX 3 , 5 and 8 weeks, $n=5), n=15$ (OVX-E 3, 5 and 8 weeks, $n=5), n=15$ (OVX-I 3, 5 and 8 weeks, $n=5), n=15$ (OVX-A 3,5 and 8 weeks, $n=5)$.

*Values that do not share the same superscript letters are significantly different from each other $(p<0.05)$.

\section{Cell size of the granular ducts}

The morphological appearance of the granular ducts is shown in Figure 1.

ANOVA showed that the time of euthanasia, the experimental group and the interaction between them had significant effects $(\mathrm{p} \leq 0.05)$. The SHAM group showed the largest mean cell area at 3 weeks, similar to the OVX-A group for the same period. At five and eight weeks, mean cell size remained similar between all the groups, except for OVX-A at eight weeks (Figure 3).

\section{PCNA in acinar cells}

The ANOVA test was applied to the value of positive acinar cells of a total of 300 cells and showed as significant effect, the experimental group ( $\mathrm{p}=0.003$ ). The Tukey test showed no differences between treated groups in 3, 5 and 8 weeks. Group OVX-A presented the highest value at 5 weeks, marginally above most others, with the exception of SHAM at 8 weeks (Figure 4). 


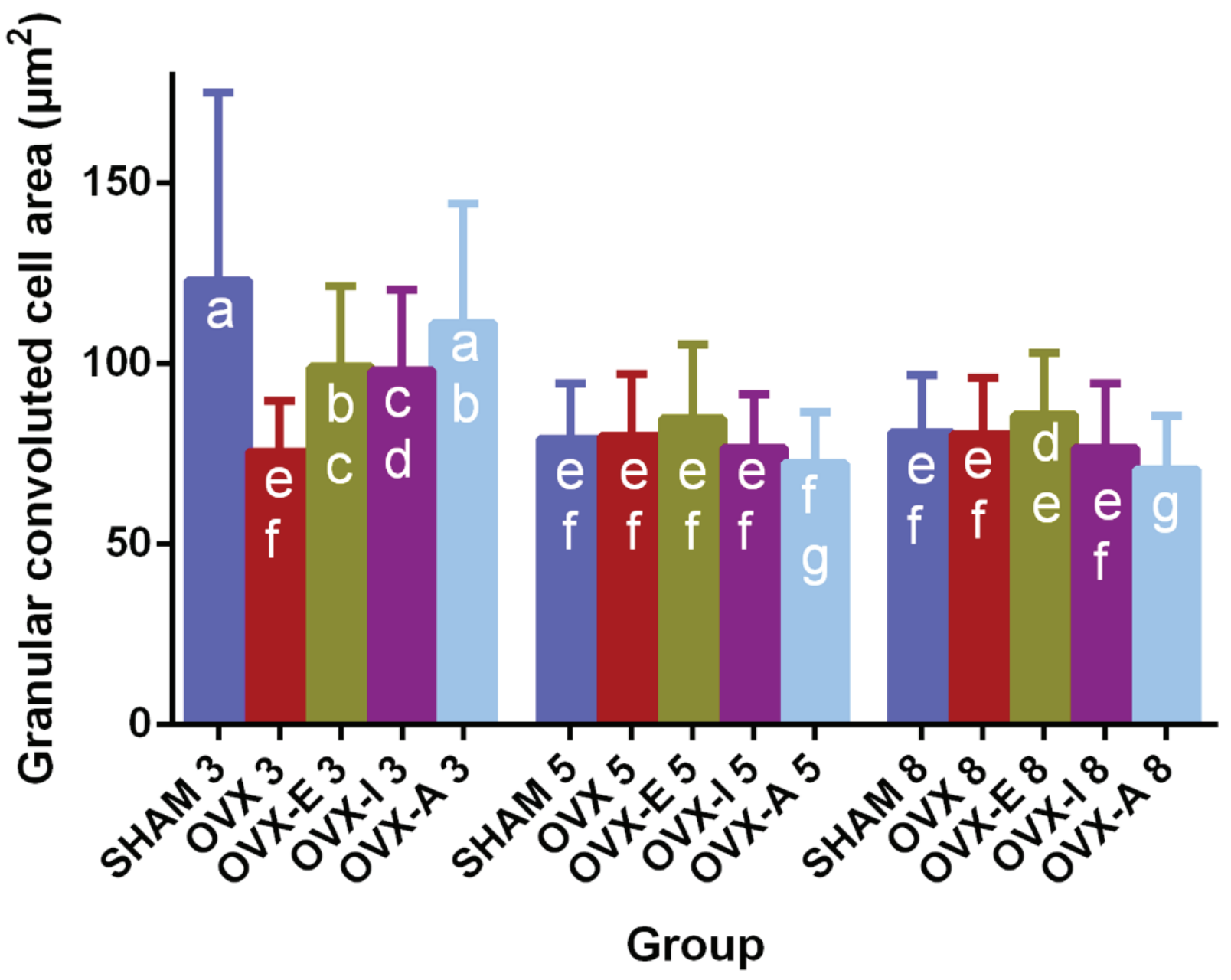

Figure 3 - Effects of ovariectomy and different treatments on GCT cells. Bar charts indicate the average and standard deviation for each group. The number of animals evaluated for each cohort was $n=15$ (Sham 3, 5 and 8 weeks, $n=5$ ), $n=15$ (OVX 3, 5 and 8 weeks, $n=5), n=15$ (OVX-E 3, 5 and 8 weeks, $n=5$ ), $n=15$ (OVX-I 3, 5 and 8 weeks, $n=5$ ), $n=15$ (OVX-A 3, 5 and 8 weeks, $n=5$ ). *Values that do not share same superscript letters are significantly different from each other $(p<0.05)$. 


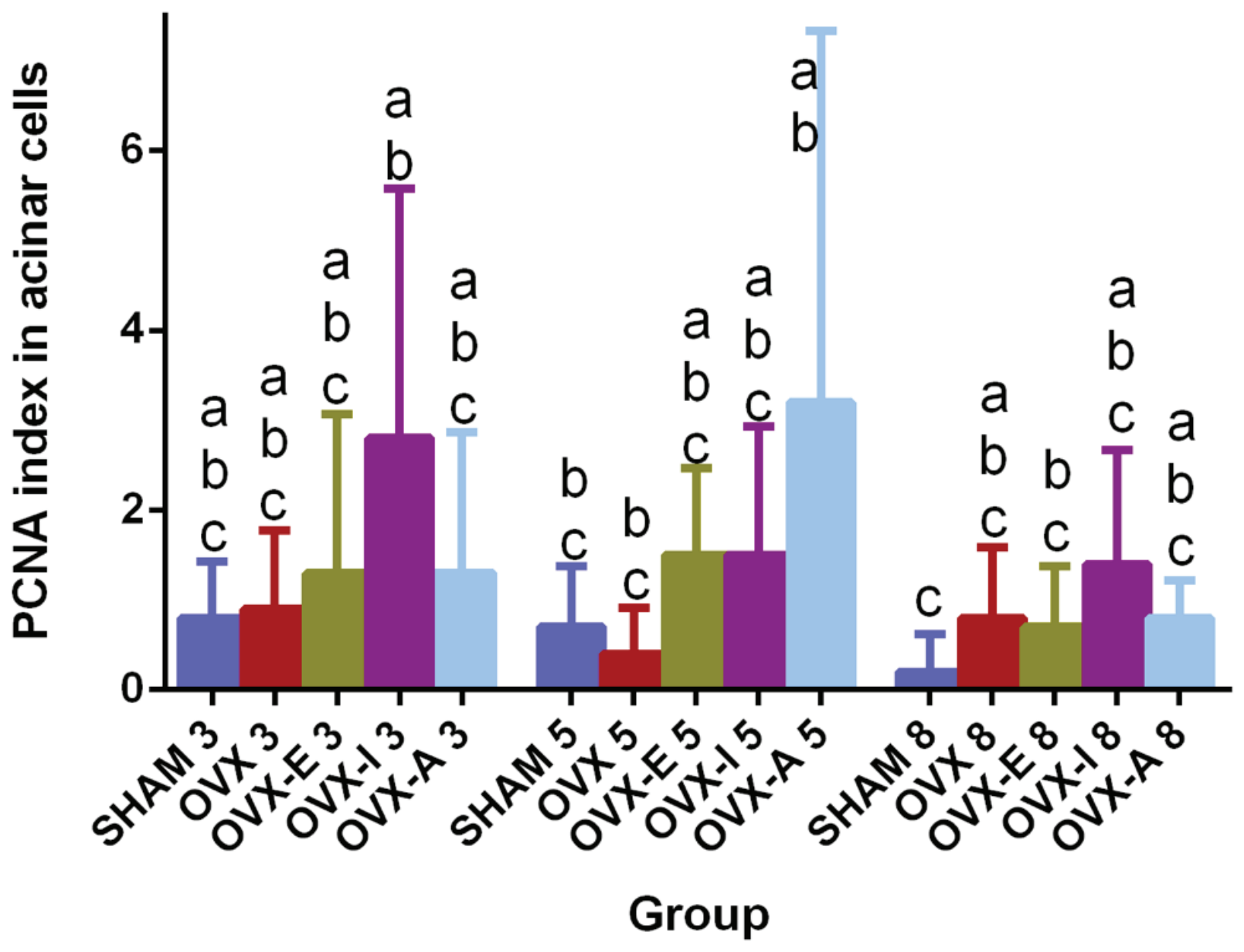

Figure 4 - Effects of ovariectomy and different treatments on acinar cell proliferation. Bar charts indicate the average and standard deviation for each group. The number of animals evaluated for each cohort was $n=15$ (Sham 3,5 and 8 weeks, $n=5)$, $n=15$ (OVX 3 , 5 and 8 weeks, $n=5), n=15$ (OVX-E 3, 5 and 8 weeks, $n=5), n=15$ (OVX-I 3, 5 and 8 weeks, n=5), $n=15$ (OVX-A 3,5 and 8 weeks, $n=5$ ). *Values that do not share same superscript letters are significantly different from each other $(p<0.05)$.

\section{PCNA in cells of the granular ducts}

In cells of the granular ducts, ANOVA showed that the time of euthanasia and its interaction with the experimental group had significant effects $(\mathrm{p}=0.004$ and $\mathrm{p}=0.015$ respectively). At 5 weeks, the OVX-A group presented the highest value, but was statistically similar to OVX-I (Figure 5).

\section{Estrogen receptor- $\beta$}

The expression of estrogen receptor- $\beta$, predominantly in granular ducts, is shown in Figure 6.
ANOVA showed a significant effect for experimental group ( $\mathrm{p}=0.003)$. At 5 weeks, the OVX-I group showed the highest expression, though this was very similar to the OVX-E, OVX-I, OVX,OVX-A and SHAM for different periods of euthanasia (Figure 7). 


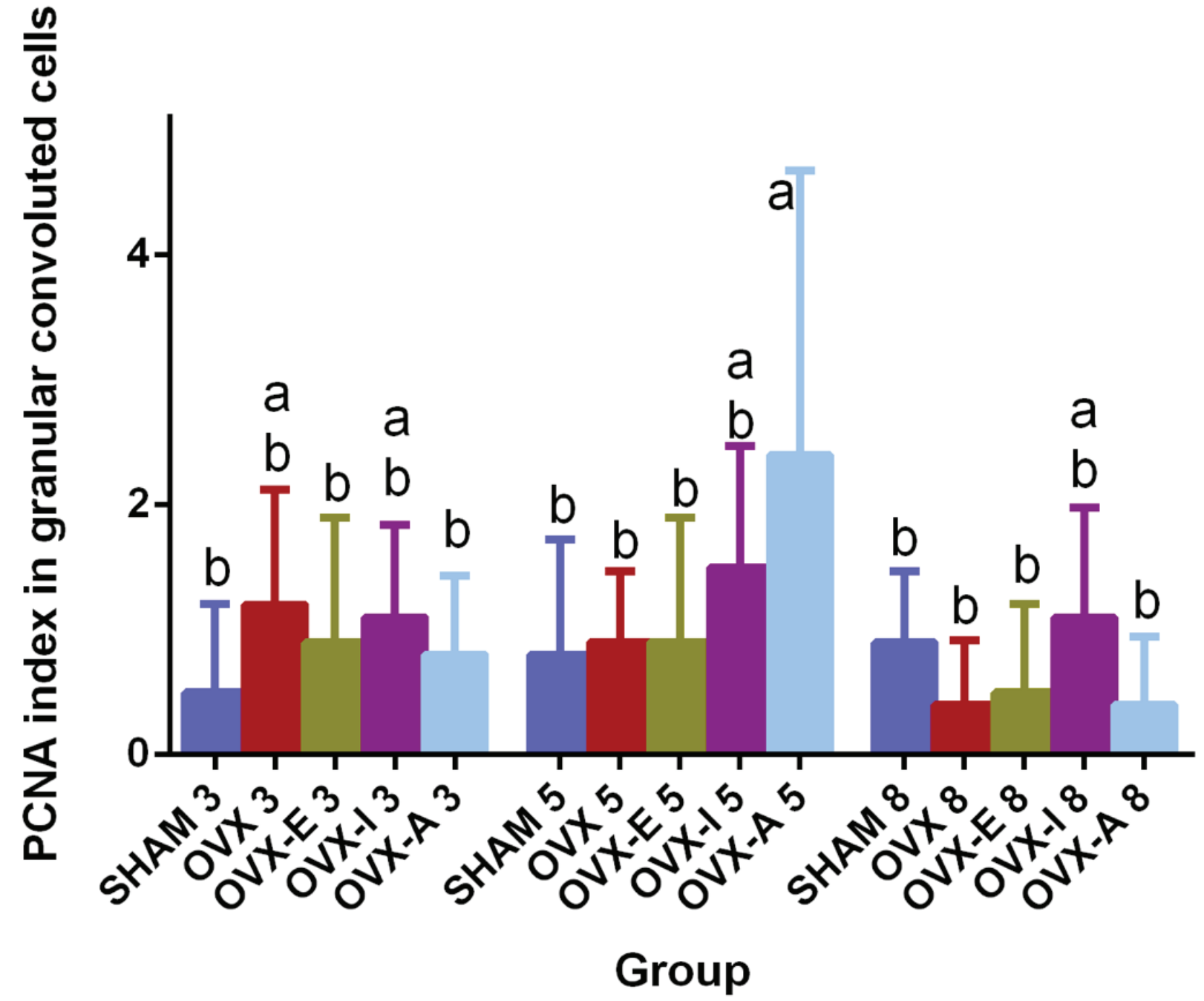

Figure 5 - Effects of ovariectomy and treatments on GCT cell proliferation. Bar charts indicate the average and standard deviation for each group. The number of animals evaluated for each cohort was $n=15$ (Sham 3,5 and 8 weeks, $n=5), n=15$ (OVX 3,5 and 8 weeks, $n=5), n=15$ (OVX-E 3, 5 and 8 weeks, $n=5), n=15$ (OVX-I 3, 5 and 8 weeks, $n=5), n=15$ (OVX-A 3, 5 and 8 weeks, $n=5)$.

*Values that do not share same superscript letters are significantly different from each other $(p<0.05)$ 


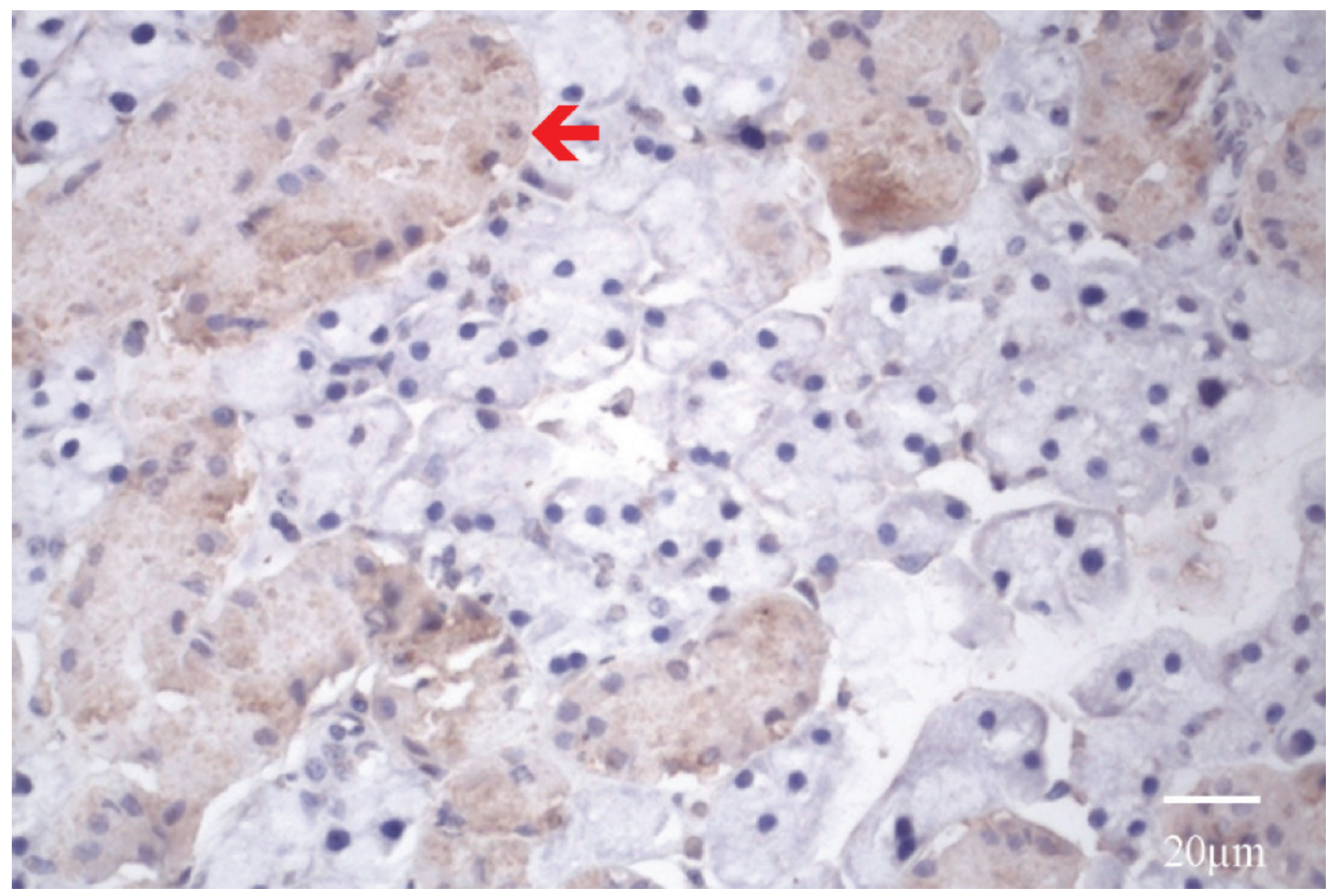

Figure 6 - Immunohistochemical location of estrogen receptor- $\beta$ (ER- $\beta$ ) in light microscopy imaging clearly showing positive immunostaining predominantly in the submandibular gland GCT cells (red arrow). Section was originally photographed with $400 \mathrm{~A}$ magnification. 


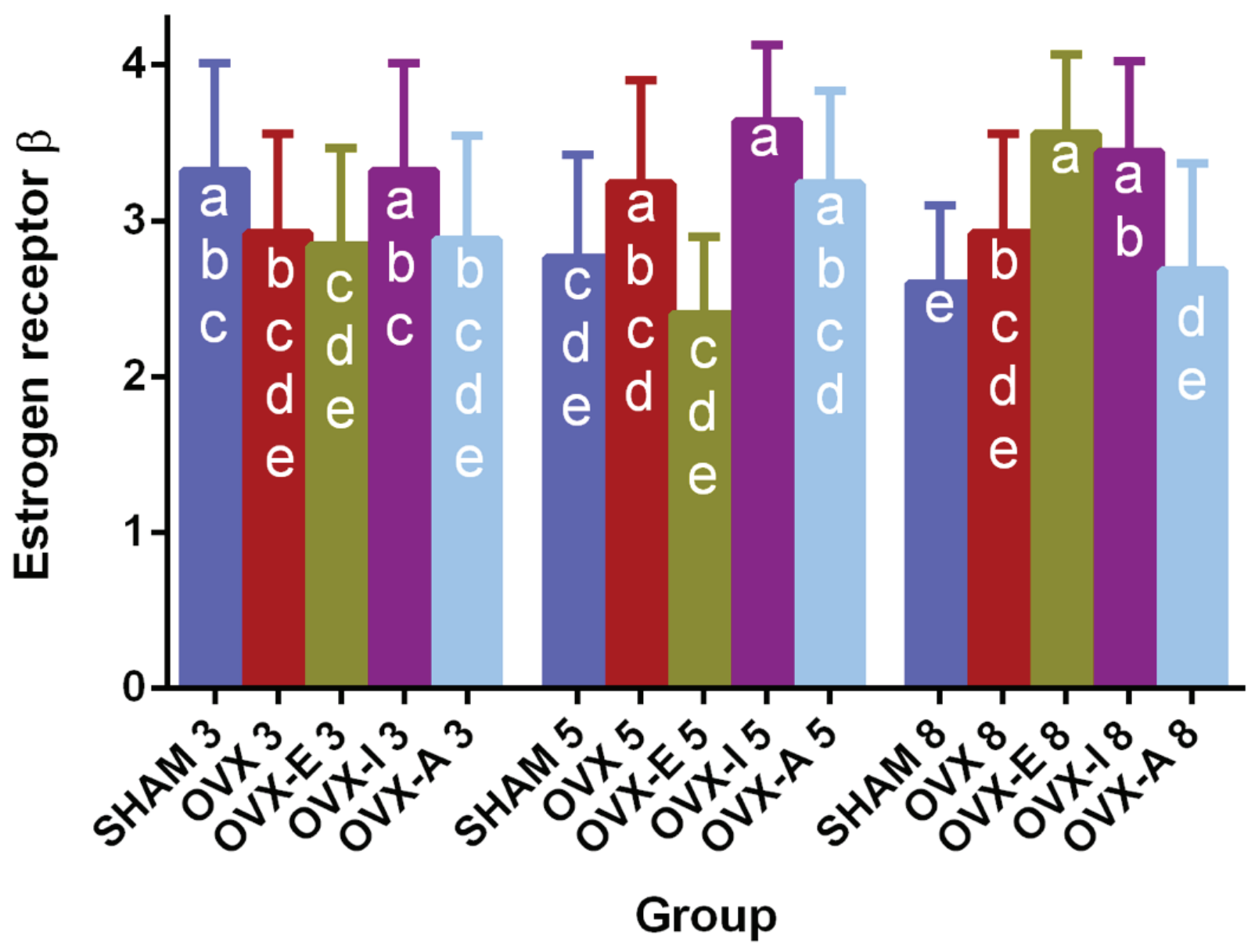

Figure 7 - Effects of ovariectomy and different treatments on the expression of ER- $\beta$. Bar charts indicate the average and standard deviation for each group. The number of animals evaluated for each cohort was $n$ O 15 (Sham 3, 5 and 8 weeks, $n=5)$, $n=15$ (OVX 3 , 5 and 8 weeks, $n=5), n=15$ (OVX-E 3, 5 and 8 weeks, $n=5), n=15$ (OVX-1 3, 5 and 8 weeks, $n=5), n=15$ (OVX-A 3, 5 and 8 weeks, n=5). *Values that do not share same superscript letters are significantly different from each other $(p<0.05)$.

\section{DISCUSSION}

Hormonal interference in the phenotypic aspects of rats submandibular glands was the target of this study. The dose of estradiol valerate in this study was based in Mvondo et al. [13] that conducted a study based on various estradiol doses, using a postmenopause-like model of ovariectomized Wistar rats to evaluate the estrogen like effects of an isoflavone and a flavanone derived from E. lysistemon. Also, to determine the dose, we drew from our own experience, gained from previous research [17], as well as from consulting other works $[16,18]$.

Other papers using higher doses were also consulted. Learning and memory in ovariectomized rats appears to be affecting by administration of high exogenous levels of estradiol $(4 \mathrm{mg} / \mathrm{kg} \mathrm{BW})$, due to enhance oxidative stress [19]. Estrogen therapy (weekly injections of estradiol valerate $(2 \mathrm{mg} / \mathrm{kg}$; i.m.) in OVX rats improved spatial memory retention in the test to find hidden platform [20]. Doses of $3,9 \mathrm{mg} / \mathrm{kg}$ diet of $17-\beta$ estradiol suppressed the OVX induced body weight increase and maintained bone density at SHAM levels [21].

Phytoestrogens, particularly in isoflavones exhibit both agonist and antagonist actions, depending on serum estrogen concentrations, estrogen receptors, etc[22]. Isoflavones have greater binding affinity for estrogen receptor- $\beta$ (ER $\beta)$ than ER $\alpha$ [18]. The standard isoflavone 
soybean extract at $40 \%$ concentration is widely documented in literature [23-25], occasionally being recommended as an alternative to the use of estrogen against menopause signs and symptoms [15,25-27]. We chose isoflavone soy extract at $40 \%$ concentration to be evaluated in this research because salivary glands present its most important target, the type- $\beta$ estrogen receptor [28].

We tested the hypothesis that ovariectomy decreases the volume of the cells of the acini and granular ducts by histomorphometric analysis of cell area using stereological principles. The results of this research showed that estrogen deficiency caused a reduction in the area of cells of the granular convoluted tubules in accordance with Kouidhi et al. [29] and Sakabe et al. [30] previous statements

The influence of sex hormones observed in granular convoluted tubule cells did not occur in the acinar cells. This was confirmed by the similarity of cell size in groups SHAM and OVX for all experimental periods, although subtle differences were observed when compared to the other groups. Additionally, the area of granular convoluted tubule cells had similar values at 5 and 8 weeks in both SHAM and OVX. It has been proposed that fatty tissue can provide a source of estrogenic hormones in ovariectomized rats [31], which may justify these findings, as ovariectomy was successfully confirmed by uterine atrophy. When comparing weight, greater gain among rats with hormonal deficiency was observed when compared to the control group.

We observed the effects of ovariectomy on the salivary glands in periods of 3, 5 and 6 weeks. Time was statistically significant for the reduction in the areas of acinar and GCT cells, as well as PCNA rates. Seko et al. [9] performed oral mucosa analysis after periods of 2,4 and 6 months after ovariectomy. The thinning of oral mucosa epithelium was most obvious in the apex (tip) of the tongue by 6 months after ovariectomy. In contrast, in our study not only OVX groups had a reduction in cell area, SHAM groups also presented significantly smaller values after 5 and 8 weeks compared to 3 weeks.

A passenger effect of estrogen deficiency on cell size of the granular convoluted tubules became apparent, since the statistical difference was observed only in rats euthanized at 3 weeks. SHAM and OVX at 5 and 8 weeks were similar. Administering an association of estrogen and soy isoflavones returned the volume of the cells of the granular convoluted tubules to control values of the sham-operated group. The groups administered isoflavones or estrogen alone showed values superior to the OVX group at 3 weeks. This corroborates the fact that the cells of the granular convoluted tubules are under the multihormonal regulation by androgens, thyroid and adrenocortical hormones [32]. In male mice, such cells are voluminous and contains abundant large secretory granules, while female mice contain fewer secretory granules of smaller volume, thus showing a sexually dimorphic pattern [32].

The alteration in the cell volume of the OVX group reflects the reduction of estrogenregulated secretory granules [32]. The results showed that estrogen therapy increased the volume of granular convoluted tubules cells compared with the ovariectomized group.

Ovariectomy did not reduce the immunohistochemical expression of estrogen- $\beta$ receptors in the submandibular salivary glands. Most of the samples showed predominant expression of hormone receptors in the cytoplasm of the granular convoluted tubules cells. The literature affirms that the level of expression of the androgen receptor is variable [33-35]. The nucleus of acinar, granular and intercalated duct cells was the principal site of expression of this receptor in the study by Sawada et al. [34]. Herein we demonstrated that groups receiving soy isoflavones stood out, with high levels of estrogen receptor- $\beta$ expression at 3 and 8 weeks.

PCNA was influenced by association and estrogen therapies, partially in line with the results found by Gallo et al., which showed 
an increase in Ki67 immunoreactivity by $17 \beta$-estradiol, although it remained unchanged after soy extract treatment when compared with OVX controls.

Considering the decreased volume of granular cells as a result of ovariectomy (reduced estrogen), we expected to detect reduced expression of estrogen receptor, which did not occur. Apparently, other factors influence cells volume, such as epidermal growth factor (EGF) [36] which appears to regulate the phenotype of granular rodent cells. In males, the expression of EGF is higher than female rats [32]. Pascall et al. [37] showed that the expression of EGF increases in castrated female rats and decreases in castrated male rats. It is possible that the expression of EGF increased in the groups of castrated rats (however, in this research, it was not assessed) and could have affected the volume of the cells of the granular convoluted tubules.

Acinar cells showed similar volumes in all groups. Our study confirms the findings reported by Morrell et al. [33], who affirmed that the acinar cells are not affected by sex hormones, either structurally or in their composition.

Soy isoflavones and their association with estrogen caused an increase in the proliferation in acini cells compared with the SHAM group. None of the groups presented statistically significant differences for cell proliferation in the granular convoluted tubules. Soy isoflavones exert different cellular effects that can include inducing the activation of estrogen receptor- $\alpha$, which promotes cell proliferation, and estrogen receptor- $\beta$, which promotes apoptosis. An irregular dose response to isoflavones has been observed, mainly relating to ability of cells to stimulate proliferation. Isoflavones appear to modulate epigenetic mechanisms, including DNA methylation, histone modifying genes and noncoding RNAs [38]. Some of the genes suffering DNA methylation, after exposure to high or low doses of isoflavones [39], regulate the proliferation of mammary epithelial cells. Our study has effectively demonstrated the differential expression of a proliferation marker in castrated rats induced by isoflavones. Epigenetic changes are potentially the mechanism involved in this phenomena. It is important to remember that soybeans, don't present a constant isoflavone content, instead their content is subject to a variety of environmental factors such as temperature, precipitation [40], the location of crops and the season they are planted [41].

The capacity to conjugate isoflavones also fluctuates significantly between mice and rats, as well as between rodents and humans, who have advanced capacity to conjugate isoflavones [42]. Following a dose of $50 \mathrm{mg} / \mathrm{kg} /$ day of soy isoflavones extract, serum levels in SpragueDawley castrated female rats were found to be $0.03 \mu \mathrm{m}$ of free genistein from a total of $0.91 \mu \mathrm{m}$, and $0.06 \mu \mathrm{m}$ of free daidzein from a total of $1.5 \mu \mathrm{m}[16]$. This dose was similar to the one we administered in our study.

Therapy with soy isoflavones promoted increased expression of estrogen receptors- $\beta$ in the submandibular salivary glands. Perhaps this mechanism of increased estrogen receptors, associated with the induction of increased cell proliferation, explain the results obtained by Chaves Carvalho et al. [4] in which isoflavones maintained a volume density in the treated rats similar to that of the SHAM group rats.

The cells of the granular convoluted tubules of rats administered soy isoflavones presented less volume than those of the SHAM group for all the experimental periods. Estrogenic hormones have numerous effects on cells of the salivary glands, differing depending on the cell type.

A clear dose response pattern cannot always be observed [39]. According Blei et al., an isoflavone dose that reflects a lifelong nutritional exposure via a soy rich diet may be sufficient to result in an increase in fat metabolism, protein synthesis and skeletal muscle mass. In cell cultures, the mechanism behind proliferation 
and anti-proliferative action of isoflavones is unknown, but non-linear dose response curves have been described, showing proliferation of MCF-7 cells in vitro.

PCNA expression remained similar in the granular convoluted tubules and acini of rats treated with $17 \beta$-estradiol. A similar result was reported by Tsinti et al. [5]; however, in their study, the volume of granular cells returned to normal following hormone therapy. This estrogen-dependent mechanism explains the results obtained by Chaves Carvalho et al. [4], who verified similar volume densities in the groups administered estrogen and shamoperated rats.

\section{CONCLUSION}

Castration exerts almost immediate reductive effect on the cell volume of the granular convoluted tubules of the submandibular gland of rats. Estrogens and soy isoflavones alone and in combination have different mechanisms of action on the homeostasis of the tissue, such that the first causes an increase in the volume of normal cells of the granular convoluted tubules, the second enhances the expression of estrogen receptor- $\beta$, while their association showed no combined or additional increase in the effect studied.

\section{ACKNOWLEDGEMENTS}

The authors thank FAPESP (São Paulo State Research Foundation) for the scholarship (PROC 2012/00607-0).

\section{REFERENCES}

1. Soules MR, Sherman S, Parrott E, Rebar R, Santoro N, Utian W, et al. Executive summary: stages of reproductive aging workshop (STRAW). Climacteric. 2001 Dec;4(4):267-72.

2. BenAryeh H, Gottlieb I, IshShalom S, David A, Laufer D. Oral complaints related to menopause. Maturitas. 1996 Jul;24(3):185-9.

3. Giuca MR, Carli E, Pasini M, Bonfigli D, Cappe MR. Evaluation of efficacy of estrogen and phytotherapy in oral cavity alterations of women in menopause. Minerva Ginecol. 2009 Feb;61(1):13-22.

4. Carvalho VD, Silveira VÁ, do Prado RF, Carvalho YR. Effect of estrogen therapy, soy isoflavones, and the combination therapy on the submandibular gland of ovariectomized rats. Pathol Res Pract. 2011 May 15;207(5):300-5. doi: 10.1016/j.prp.2011.01.002. Epub 2011 Apr 21.

5. Tsinti M, Kassi E, Korkolopoulou P, Kapsogeorgou E, Moutsatsou $P$, Patsouris E, et al. Functional estrogen receptors alpha and beta are expressed in normal human salivary gland epithelium and apparently mediate immunomodulatory effects. Eur J Oral Sci. 2009 0ct;117(5):498-505. doi: 10.1111/j.1600-0722.2009.00659.x.

6. Treister NS, Richards SM, Suzuki T, Jensen RV, Sullivan DA. Influence of androgens on gene expression in the BALB/c mouse submandibular gland. J Dent Res. 2005;84(12):1187-92.

7. Treister NS, Richards SM, Rowley P, Jensen RV, Sullivan DA. Influence of testosterone on gene expression in the ovariectomized mouse submandibular gland. Eur J Oral Sci. 2006 Aug;114(4):328-36

8. Leimola-Virtanen R, Salo T, Toikkanen S, Pulkkinen J, Syrjanen S. Expression of estrogen receptor (ER) in oral mucosa and salivary glands. Maturitas. 2000 Aug 31;36(2):131-7.

9. Seko K, Kagami H, Senga K, Ozeki K, Mizutani H, Ueda M. Effects of ovariectomy and estrogen replacement on rat oral mucosa. Maturitas. 2005 Jan 10;50(1):44-51.

10. Streckfus CF, Baur U, Brown LJ, Bacal C, Metter J, Nick T. Effects of estrogen status and aging on salivary flow rates in healthy Caucasian women. Gerontology. 1998;44(1):32-9.

11. Cheong JM, Martin BR, Jackson GS, Elmore D, McCabe GP, Nolan JR, et al. Soy isoflavones do not affect bone resorption in postmenopausal women: a dose-response study using a novel approach with 41Ca. J Clin Endocrinol Metab. 2007 Feb;92(2):57782. Epub 2006 Dec 5.

12. Katz J, Blake E, Medrano TA, Sun Y, Shiverick KT. Isoflavones and gamma irradiation inhibit cell growth in human salivary gland cells. Cancer Lett. 2008 0ct 18;270(1):87-94. doi: 10.1016/j. canlet.2008.04.051. Epub 2008 Jun 27.

13. Mvondo MA, Njamen D, Fomum ST, Wandji J, Vollmer G. A postmenopause-like model of ovariectomized Wistar rats to identify active principles of Erythrina lysistemon (Fabaceae). Fitoterapia. 2011 0ct;82(7):939-49. doi: 10.1016/j.fitote.2011.05.009. Epub 2011 May 23.

14. Genovese MI, Pinto MdS, Barbosa ACL, Lajolo FM. Avaliação do teor de isoflavonas de "suplementos nutricionais à base de soja". Braz J Pharmaceutic Sci. 2003;39(2):159-67.

15. Catania MA, Crupi A, Firenzuoli F, Parisi A, Sturiale A, Squadrito $F$, et al. Oral administration of a soy extract improves endothelial dysfunction in ovariectomized rats. Planta Med. 2002 Dec;68(12):1142-4.

16. Gallo D, Zannoni GF, Apollonio P, Martinelli E, Ferlini C, Passetti G, et al. Characterization of the pharmacologic profile of a standardized soy extract in the ovariectomized rat model of menopause: effects on bone, uterus, and lipid profile. Menopause. 2005 Sep0ct;12(5):589-600. Epub 2005 Sep 1.

17. Spalding M, Ferreira Amschlinger $P$, de Vasconcellos $L M$, de Morais Gouvea Lima G, Kerbauy WD, Balducci I, et al. Evaluation of different periods of estrogen replacement onset in the tibia of ovariectomized rats. Aging Clin Exp Res. 2014 0ct;26(5):465-71. doi: 10.1007/s40520-014-0268-1. Epub 2014 Aug 26.

18. Gallo D, Zannoni GF, Martinelli E, Ferlini C, Fabrizi M, Riva A, et al. Estradiol and phytoestrogens differently influence the rodent postmenopausal mammary gland. Menopause. 2006 JanFeb;13(1):72-9. 
19. Khodabandehloo F, Hosseini M, Rajaei Z, Soukhtanloo M, Farrokhi E, Rezaeipour M. Brain tissue oxidative damage as a possible mechanism for the deleterious effect of a chronic high dose of estradiol on learning and memory in ovariectomized rats. Arq Neuropsiquiatr. 2013 May;71(5):313-9.

20. Ma X, Zhang H, Wang K, Yang L, Qin L, Bai W, et al. Effects of an isopropanolic-aqueous black cohosh extract on central body temperature of ovariectomized rats. J Ethnopharmacol. $20110 \mathrm{ct}$ 31;138(1):156-61. doi: 10.1016/j.jep.2011.08.076. Epub 2011 Sep 8.

21. Lee YB, Lee HJ, Kim KS, Lee JY, Nam SY, Cheon SH, et al. Evaluation of the preventive effect of isoflavone extract on bone loss in ovariectomized rats. Biosci Biotechnol Biochem. 2004;68(5):1040-5.

22. Kuiper G, Lemmen JG, Carlsson B, Corton JC, Safe SH, van der Saag PT, et al. Interaction of estrogenic chemicals and phytoestrogens with estrogen receptor beta. Endocrinology. 1998 0ct;139(10):4252-63.

23. Baumgartner-Parzer SM, Waldenberger FR, Freudenthaler A, Ginouves-Guerdoux A, McGahie D, Gatto H. The natural antioxidants pomegranate extract and soy isoflavones favourably modulate canine endothelial cell function. ISRN Vet Sci. 2012 Nov 26;2012:590328. doi: 10.5402/2012/590328. Print 2012.

24. Llaneza P, Gonzalez C, Fernandez-Inarrea J, Alonso A, Diaz F, Perez-Lopez FR. Soy isoflavones improve insulin sensitivity without changing serum leptin among postmenopausal women. Climacteric. 2012 Dec;15(6):611-20. doi: 10.3109/13697137.2011.631062. Epub 2011 Dec 23.

25. Toccafondo Vieira MdL, Duarte RF, Moreira Campos LM, Nunan EdA. Comparison of the estrogenic potencies of standardized soy extracts by immature rat uterotrophic bioassay. Phytomedicine. 2008 Jan;15(1-2):31-7. Epub 2007 Aug 8.

26. Cancelo Hidalgo MJ, Castelo Branco C. Optimizing soy isoflavones effect in postmenopausal women: the impact of timing on climacteric symptoms. Gynecol Endocrinol. 2011 Sep;27(9):696700. doi: 10.3109/09513590.2010.526665. Epub 2010 Oct 28.

27. Chang K-L, Hu Y-C, Hsieh B-S, Cheng H-L, Hsu H-W, Huang L-W, et al. Combined effect of soy isoflavones and vitamin D3 on bone Ioss in ovariectomized rats. Nutrition. 2013 Jan;29(1):250-7. doi: 10.1016/j.nut.2012.03.009. Epub 2012 Aug 2.

28. Valimaa H, Savolainen S, Soukka T, Silvoniemi P, Makela S, Kujari H et al. Estrogen receptor-beta is the predominant estrogen receptor subtype in human oral epithelium and salivary glands. J Endocrinol. 2004 Jan;180(1):55-62.

29. Kouidhi W, Desmetz C, Nahdi A, Berges R, Cravedi J-P, Auger J, et al. In utero and lactational exposure to low-dose genisteinvinclozolin mixture affects the development and growth factor mRNA expression of the submandibular salivary gland in immature female rats. Toxicol Pathol. 2012 Jun;40(4):593-604. doi: 10.1177/0192623311436183. Epub 2012 Feb 7.

30. Sakabe K OM, Okuma M, Yoshida Y, Aikawa H, Kinoue T, Kayama F. Natural and environmental oestrogens increase expression of SS-
$A: R o$ autoantigen in the salivary gland of ovariectomized immature rats. Pathophysiol. 2000;6(4):231-6.

31. Hollinger J, Wong ME. The integrated processes of hard tissue regeneration with special emphasis on fracture healing. Oral Surg Oral Med Oral Pathol Oral Radiol Endod. 1996 Dec;82(6):594-606.

32. Miyaji Y, Aiyama S, Kurabuchi S. Strain-specific and endocrine control of granular convoluted tubule cells and epidermal growth factor expression in the mouse submandibular gland. Anat Rec (Hoboken). 2008 Jan;291(1):105-13.

33. Morrell Jl, Gresik EW, Barka T. Autoradiographic localization of dihydrotestosterone binding in the major salivary glands and other androgen-responsive organs of the mouse. J Histochem Cytochem. 1987 0ct;35(10):1053-8.

34. Sawada K, Noumura T. Developmental pattern of androgen receptor immunoreactivity in the mouse submandibular-gland. Zoolog Sci. 1995 Apr;12(2):243-8.

35. Sakabe K, Seiki K, Fujiihanamoto H, Kawashima I. Progestin and estrogen-receptors - characterization and localization in rat submandibular glands, with special reference to epidermal growth-factor. Endocrinol Jpn. 1988 0ct;35(5):709-23.

36. Young WG, Ramirez-Yanez G0, Daley TJ, Smid JR, Coshigano KT, Kopchick JJ, et al. Growth hormone and epidermal growth factor in salivary glands of giant and dwarf transgenic mice. J Histochem Cytochem. 2004 Sep;52(9):1191-7.

37. Pascall JC, Saunders J, Blakeley DM, Laurie MS, Brown KD. Tissuespecific effects of castration and ovariectomy on murine epidermal growth factor and its mRNA. J Endocrinol. 1989 Jun;121(3):501-6.

38. Rietjens IM, Sotoca AM, Vervoort J, Louisse J. Mechanisms underlying the dualistic mode of action of major soy isoflavones in relation to cell proliferation and cancer risks. Mol Nutr Food Res. 2013 Jan;57(1):10013. doi: 10.1002/mnfr.201200439. Epub 2012 Nov 23.

39. Blei T, Soukup ST, Schmalbach K, Pudenz M, Moller FJ, Egert B, et al. Dose-dependent effects of isoflavone exposure during early lifetime on the rat mammary gland: Studies on estrogen sensitivity, isoflavone metabolism, and DNA methylation. Mol Nutr Food Res. 2015 Feb;59(2):270-83. doi: 10.1002/mnfr.201400480. Epub 2014 Dec 18.

40. Kim EH, Kim SL, Kim SH, Chung IM. Comparison of Isoflavones and Anthocyanins in Soybean Glycine max (L.) Merrill Seeds of Different Planting Dates. Journal of Agricultural and Food Chemistry. 2012;60(41):10196-202.

41. Wang HJ, Murphy PA. Isoflavone content in commercial soybean foods. J Agricult Food Chem. 1994;42(8):1666-73.

42. Setchell KD, Brown NM, Zhao X, Lindley SL, Heubi JE, King EC, et al. Soy isoflavone phase II metabolism differs between rodents and humans: implications for the effect on breast cancer risk. Am J Clin Nutr. 2011 Nov;94(5):1284-94. doi: 10.3945/ajcn.111.019638. Epub 2011 Sep 28

\section{Renata Falchete do Prado (Corresponding address)}

Departamento de Biociências e Diagnóstico Bucal

Av. Engenheiro Francisco José Longo, 777,

Jardim São Dimas, São José dos Campos, São Paulo,

CEP 12245000, Brazil.

Date submitted: 2017 Jun 07

renatafalchete@hotmail.com 